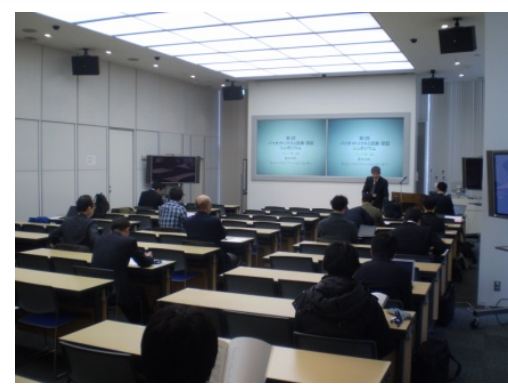

SBRA2012での講演の様子

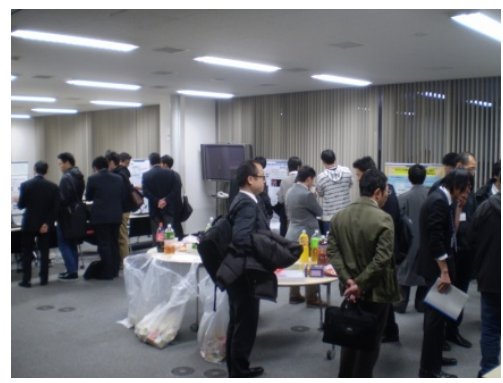

ポスター・デモ・展示の様子

最後に来年度の研究会開催計画を示します。

6 月

9月

11 月

2015 年

3月
北陸支部：映像情報メディア学会映像メディア工学研究会 (ME), 情報センシング研究会 (IST) と共催 信越支部：MEとバイオサイバネティックス研究会 (MBE) と併催 東京支部：SBRA2014 と連催

東京支部:パターン認識・メディア理解研究会 (PRMU) と共催

現時点では日時や場所は未定です，今後の詳細についてはホームページで発表していきますので, 御覧下さい.

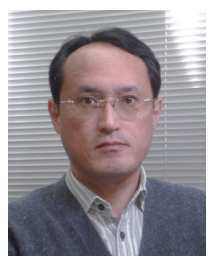

中西 功 (正員: シニア会員)

昭 59 阪府大·工·電気卒. 昭 61 同大学院修士課 程了。同年三洋電機 (株) 入社, 平4 只鳥取大·教 育·講師, 現在, 同大学・工・准教授。博士 (工学) 平19〜20アメリカ合衆国ミシガン州立大訪問研究 員.ディジタル信号処理, 特に適応フィル夕, 音声信 号処理, 生体認証に関する研究に従事. 現在, バイオ メトリクス時限研究專門委員会委員長.

\title{
複雑コミュニケーションサイエンス時限研究会 (CCS)
}

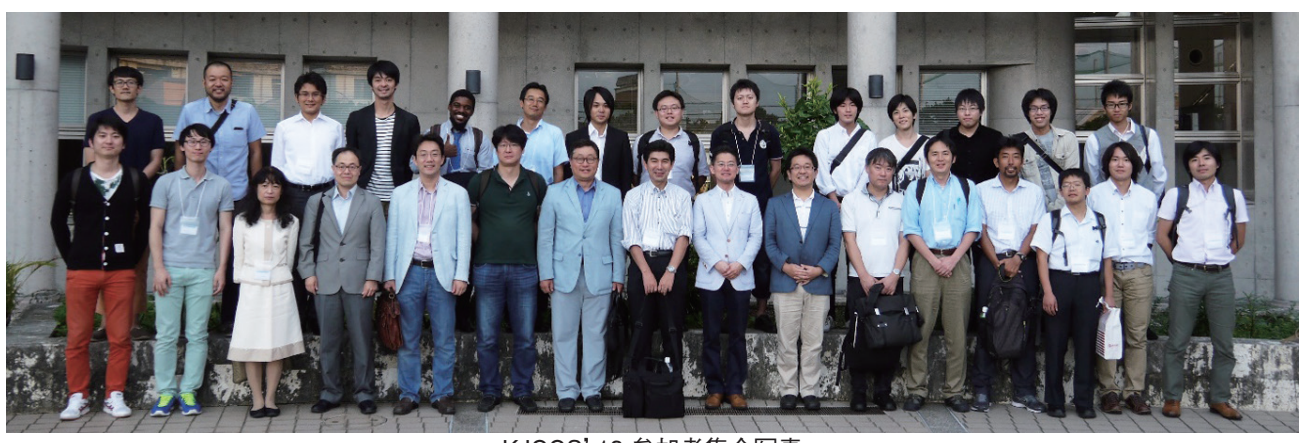

KJCCS' 13 参加者集合写真

複雑コミュニケーションサイエンス時限研究専門委員会 (CCS) は, 情報通信技術の全ての階層, それを取り巻く情報通信環境, そして神経系や生物システム, 更には人間のソーシャルコミュニケーションをも含めた広範なテーマ・問題を取り扱う研究会です CCSでは毎年4回の研究会・ワークショップを開催しており, 今年度の開催済み及び開催予定の研究会は以下のとおりです.

2013 年6月3, 4日：立命館大学

2013年8月9, 10日：北海道 (NetSci との合同ワークショップ)

2013年 10月 17〜 19日: 沖縄 (2nd Korea-Japan Joint Workshop on Complex Communication Sciences)

2014年3月3〜5日：早稲田大学 (移動通信ワークショップ(RCS, SRW, SR と併催))

これ以外に，NOLTA等の国際会議にて，CCSのスペシャルセッションを積極的に企画・開催しております，

今年度の目玉は, 何と言っても 10月に開催致しました「2nd Korea-Japan Joint Workshop on Complex Communication Sciences (KJCCS'13)」です! 近年, 韓国と日本で独自に進められているICTに関わる複雑コミュニケーションサイエンス研究 

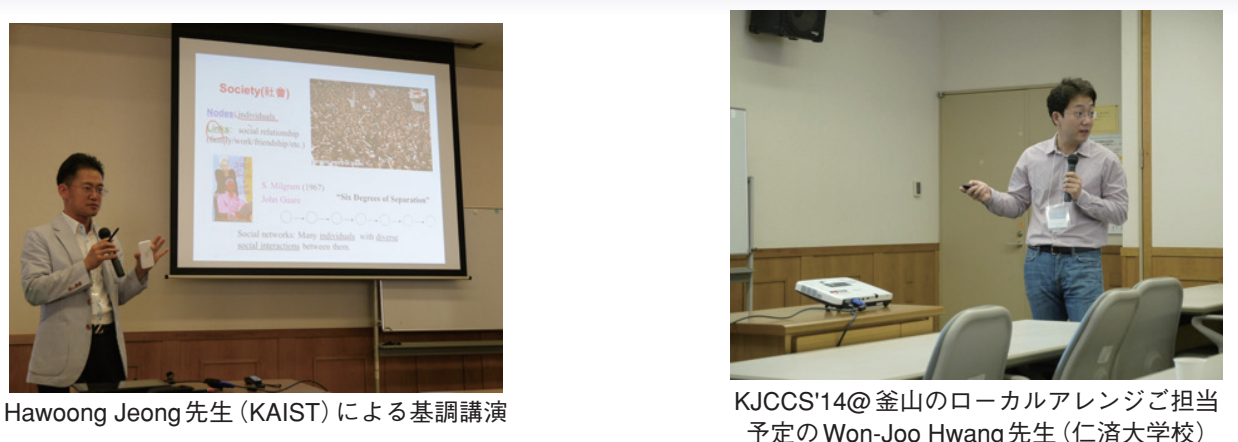

についての情報交換及び互いの交流を深めることを目的に, 昨年 11 月, 韓国ソウル市内の漢陽大学にて合同ワークショップを開 催し, 現地世話人のDong Kyue Kim 先生 (韓国, 漢陽大学) の御尽力により, 大盛況の下に終了致しました. 今後の韓国との継続 的な連携及び情報交換を目的とし, 昨年度に引き続き今年度もワークショップを開催致しました，しかも，今回はCCS 主催として は初となる国際会議としての開催，場所は沖縄です！今年の10月は台風が日本を2度も襲い, 開催が危乃゙まれましたが, 沖縄は 私達の到着を待っていたかのような天気で, まぶしい日差しが照りつける晴天の中, ワークショップは無事開催されました。

今回のワークショップでは24件(基調講演, 招待講演含む) の発表がありました。一般講演では 1 件当り 25 分の発表時間に設 定し, 発表ごとに深い議論を行えました. また, 基調講演者としてHawoong Jeong先生(韓国 KAIST), 更に招待講演者とし てMun-Kyu Lee先生 (韓国 仁荷大学校)，Won-Joo Hwang先生 (韓国 仁済大学校)，吉村和之様(NTT)に参加をお願し致しま した. どれも大变興味深い講演ばかりで,特にHawoong Jeong 先生のタブレット端末を使ったダイナミックなプレゼンテーショ ンには，多くの参加者の目がくぎ付けになりました，懇親会では，昨年伝授していただいた韓国流乾杯が至る所で繰り広げられる 大にぎわいを見せ,互いの親睦を深めることができました，特に今回は日本と韓国の学生同士も積極的に交流を深めていたようで， 将来のCCSを引っ張っていくであろう若き研究者たちの今後がとても楽しみです，

会議期間である3日間全てが活気あふれる議論の場, 交流の場として全ての参加者に楽しんでいただけと考えます，特に，韓国 側の参加者が今回のワークショップに関して大变感激して下さり, 今後も継続的なワークショップの開催を約束できたことは一番 の収穫でした，既に来年8月に同ワークショップを釜山で開催することが決定しており，今後ますますCCSが盛り上がっていく ことでしょう.

釜山でのワークショップ情報等, 本研究会の最新情報はCCS Webサイト (下記参照)に随時更新していきますので, ぜひ御参 照下さい. 最後に, CCSは現在, 常設研究專門委員会 (一種研)への昇格を申請する準備を進めております. これからもますます 活発に活動を続けるCCSに期待して下さい，そして，皆様のCCSへの御参加お待ちしております!

CCS WEBサイト http://www.ieice.org/rccs/

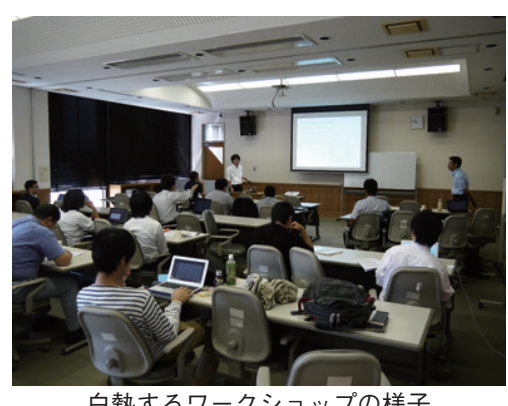

白熱するワークショップの様子

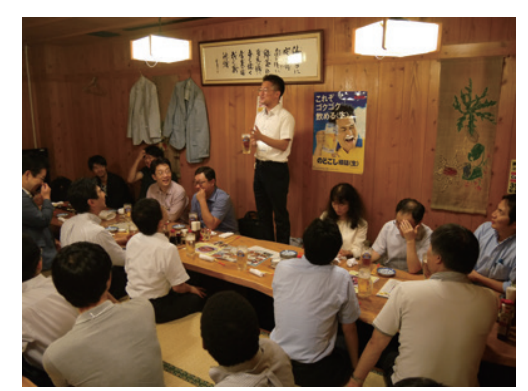

バンケットの様子

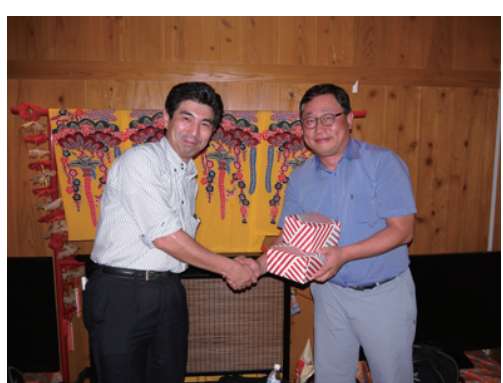

長谷川幹雄先生 (左, 東京理科大) と Dong Kyue Kim 先生 (右, 漢陽大学) の熱い友情の 握手

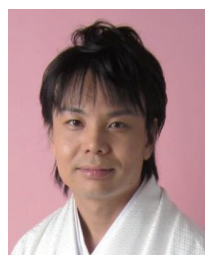

荒井伸太郎 (正員)

平 16 徳島大.工·電気電子卒. 平18同大学院修 士課程了. 平2 1 同大学院博士課程了. 博士 (工学) 同年, 愛知工科大.ITS 研究所・研究員. 平23香川 高専·通信ネットワーク工学科・助教, 現在に至る. カオスの通信システムへの応用, 可視光通信システム のITS への応用に関する研究に従事. 平20本会学術 奨励賞受賞. IEEE 会員. 